\title{
The Effects of Peroxiredoxin 6 Gene rs41055489 Variation on Oxidative Stress Mechanisms in Human Model Organism
}

\author{
Zeynep ATASAYAR ÜNVER1, Meliha KOLDEMIR GÜNDÜZ², Figen Esin KAYHAN¹, Güllü KAYMAK' \\ Ülgen ZENGIN³, Penbe ÇAĞATAY 4 , Belgin SÜSLEYICİ DUMAN ${ }^{2}$ \\ ${ }^{1}$ Department of Hydrobiology, Marmara University Faculty of Arts and Sciences, İstanbul, Turkey \\ ${ }^{2}$ Department of Molecular Biology, Marmara University Faculty of Arts and Sciences, İstanbul, Turkey \\ ${ }^{3}$ Department of Anesthesiology and Reanimation, Bezmialem Vakif University, İstanbul, Turkey \\ ${ }^{4}$ Department of Biostatistics and Medical Science, İstanbul University İstanbul Faculty of Medicine, İstanbul, Turkey
}

\section{ABSTRACT}

Objective: Peroxiredoxins (Prx) belong to peroxidase type enzyme group which reduce redox active cysteine residues. The aim of this study was to determine the allele frequencies of Prx 6 gene rs 41055489 polymorphism in zebrafish and in which extent may improve protective measures against oxidative stress indicators.

Methods: The Prx6 gene rs41055489 genotypes were determined with qPCR method in zebrafish exposed to different doses of heavy metals. Additionally, the glutathion (GSH), malondialdehide (MDA) and catalase (CAT) levels were measured.

Results: The Prx6 gene rs41055489 genotype frequencies were determined respectively as $97.7 \%$ for homozygous wild type (A/A), $2.3 \%$ for heterozygous (A/C) in group. The polymorphic genotype $(\mathrm{C} / \mathrm{C})$ was not detected in our study group.

Conclusion: Prx6 rs41055489 heterozygous gene polymorphism have been observed to inhibit defence mechanisms.

Keywords: Zebra fish, Peroxiredoxins 6 gene, rs41055489 polymorphism, heavy metal, oxidative stress

\section{Introduction}

Oxidative stress plays a role in the formation and development of many diseases. Antioxidative enzymes serve against oxidative stress in cellular defense by removing reactive oxygen species (ROS) such as superoxide and hydrogen peroxide. Changes in the activities of signaling pathways resulting from an increase in antioxidant enzyme levels provide an increased oxidative stress resistance as well as a high quality of life $(1,2)$.

Peroxiredoxins (Prxs) are members of the family of peroxidases showing a wide distribution in prokaryotic and eukaryotic organisms. Prxs are enzymes used for the reduction of hydrogen peroxide in the redox-active cysteine residue (3). The most important task of Prx is to show its antioxidative effect by reducing or inhibiting the toxic effects of organic hydroperoxides $(\mathrm{ROOH})$, peroxynitrites, and hydrogen peroxides (4). In literature, in studies performed on people, yeast, and Drosophila, Prx ROS have been reported to be involved in enzymatic transport and to protect body cells against oxidative stress (5-7). According to their catalytic mechanisms, Prxs are classified as typical 2-Cys, atypical 2-Cys, and 1-Cys (8, 9). Prx-6 is classified in the 1-Cys subgroup of the Prx family and is in charge of antioxidative events (7, 10-12). The Prx6 gene has also been identified in some aquatic species such as Laternula elliptica (13), Chinese shrimp, Fenneropenaeus chinensis (14) Haliotis discusdiscus (15), Crassostrea gigas (16), and Arenicola marina (17). This gene was sequenced in only four species of fish including Salmo salar (GenBank code. ACI 67571), Oncorhynchus mykiss (GenBank code. NP_001158604), Ictalurus punctatus (GenBank code. ABG77029), and Danio rerio (GenBank code. NP_957099) (18). The peroxiredoxin gene is located in the 1719953 rd position of the rs41055489 polymorphism in chromosome 20 (19). The rs41055489 polymorphism occurs as a result of an A-C nucleotide exchange (19). In literature, 100 single nucleotide polymorphisms belonging to the Prx-6 gene have been identified (19).

Heavy metals accumulate in the food chain through metabolically active tissues and organs. This bioaccumulation leads to functional and structural defects at the cellular and molecular level. After short-term cadmium (Cd) impact, hematological effects, disturbances in calcium balance, histopathological changes in tissues such as kidney, gills, and intestines, ion level changes of extracellular fluid and osmoregulation capacity differences can be observed in aquatic organisms (20).

Address for Correspondence: Belgin SÜSLEYici DUMAN; Marmara Üniversitesi Fen Edebiyat Fakültesi, Moleküler Biyoloji Anabilim Dall, İstanbul, Türkiye Phone: +905352913319 E-mail: belgin.susleyici@marmara.edu.tr 
Cd may disrupt basic physiological and biochemical mechanisms such as neurotransmitter, transepithelial transport, the immune system, and oxidases by influencing various enzyme systems in fish. Further, $\mathrm{Cd}$ is known to impair the balance of copper $(\mathrm{Cu})$ and zinc $(\mathrm{Zn})$ by replacing $\mathrm{Zn}$ and $\mathrm{Cu}$, which are enzyme pools in cells (21). Elevated Cu levels in cells leads to genotoxic and cytotoxic effects. $\mathrm{Cu}$ exerts its toxic effects by causing lipid peroxidation (LPO) and DNA damage and by disrupting the balance of calcium (22). Cu entering the aquatic environment first interacts with fish gills and then exerts its toxic effects on the liver and intestines in freshwater fish $(23,24)$.

In sublethal environmental concentrations of $\mathrm{Zn}$, which is a metabolic element, the growth of fish slows down; further, swimming movements and blood biochemistry change, and the spawning capacity also decreases (25). $\mathrm{Zn}$ accumulation is most frequently observed in the gills and intestines.

The purpose of this study is to determine preventive measures developed against oxidative stress markers depending on the rs41055489 genotypes of the Prx6 gene whose antioxidative effects are seen in the gills of zebrafish (D. rerio), which is an vertebrate model organism.

\section{Methods}

\section{Study group}

Forty-three pieces of zebrafish that were commercially provided were brought to the research laboratory in polyurethane bags. Zebrafish were grouped and put in seven test glass aquariums with a size of the $70 \times 30 \times 45 \mathrm{~cm}$. The water temperature in the aquarium was fixed at $26-28^{\circ} \mathrm{C}$ and the $\mathrm{pH}$ was 7 . A sufficient level of oxygen $(9-12 \mathrm{mg} / \mathrm{L})$ was pumped into the aquariums with the help of an air pump. The powder of fish feed was used to feed the fish. This feeding was repeated twice a day, in the morning and in the evening, until the fish were full. The fish were not fed during toxicological tests (26). After the adaptation of the fish to the environment, $\mathrm{Cu}$ (0.1-ppm Cu, n=6 and 0.5-ppm Cu, n=5), Zn (0.1-ppm $\mathrm{Zn}, \mathrm{n}=7$ and 0.5-ppm Zn, n=6), and Cd (0.1-ppm Cd, n=8 and 0.5 -ppm $\mathrm{Cd}, \mathrm{n}=5$ ) were added in the aquariums for $24 \mathrm{~h}$ at growing and different doses. The same physical conditions were also applied in the control group $(n=6)$. No anesthetic was given to the fish to relieve the stress. At the end of the specified test period, after the fish were numbed with cold shock for $3-5 \mathrm{~min}$ at $-20^{\circ} \mathrm{C}$, their gill tissues were quickly dissected. The gill samples taken from each fish were divided into two, and one part was used for determining the genotype, while the other was used for biochemical analysis.

\section{DNA isolation and genotype determination}

DNA isolation from gill tissues was performed in accordance with the High Pure PCR Template Preparation Kit protocol (Roche, Germany). The rs41055489 polymorphism was determined by real-time polymerase chain reaction (RT-PCR) tics, Germany). Using the LightCycler ${ }^{\circledast}$ FastStart DNA Master HybProbe kit conforming to the LightCycler 2.0 qPCR device and hybridization probe (FRET) (TIB Molbiol Kit), the genotype of the Prx-6 rs41055489 gene polymorphism was determined. Genomic DNA was isolated from the gill tissue samples of the fish groups and control group fish exposed to heavy metals such as $\mathrm{Cu}, \mathrm{Zn}$, and $\mathrm{Cd}$ using the High Pure PCR Template Preparation Kit (Roche) (27). A hybridization probe and primer sequences were used to determine the rs41055489 genotypes. Using hybridization probes of rs41055489 single nucleotide polymorphisms with the LightCycler FastStart DNA Master kit, the target area was quantitatively enlarged by the PCR LightCycler 2.0 system. Using melting curve analysis, the genotypes were determined by examining the appropriate melting temperature.

\section{Preparation of $10 \%$ tissue homogenate}

By separately washing the gill tissue samples with saline, blood was removed; the samples were dried with a filter paper and weighed. They were homogenized in a dismembrator with the help of a necessary amount of saline and glass beads. Each tissue homogenate was placed in separate Eppendorf tubes; they were tagged and stored at $-20^{\circ} \mathrm{C}$ until they were analyzed.

Determination of malondialdehyde (MDA) level in gill tissues Absorbance of the pinkish color occurring after the reaction between MDA, which is an indication of LPO in the tissues, and thiobarbituric acid was spectrophotometrically measured. The LPO levels in tissue homogenates were calculated as nmol $\mathrm{MDA} / \mathrm{mg}$ protein using the extinction coefficient (1.56.105 $\mathrm{M}^{-1} \mathrm{~cm}^{-1}$ ) determined for MDA (28).

\section{Determination of reduced glutathione (GSH) level in gill tissues}

The colored product that occurs as a result of the reaction between Ellman's reagent 5,5'-dithiobis-1,2-nitrobenzoic acid and sulfhydryl groups was spectrophotometrically evaluated. GSH levels in the homogenate were calculated as GSH $\mu \mathrm{g} / \mathrm{mg}$ protein using the dilution factor and extinction coefficient $\left(13600 / \mathrm{M}^{-1} \mathrm{~cm}^{-1}\right)$ of the yellow-colored product at $412 \mathrm{~nm}$ (29).

\section{Determination of catalase (CAT) activity in gill tissues}

CATs catalyze the conversion reaction of hydrogen peroxide $\left(\mathrm{H}_{2} \mathrm{O}_{2}\right)$ to water $\left(\mathrm{H}_{2} \mathrm{O}\right)$. This conversion can be monitored through the decrease of absorbance at $240 \mathrm{~nm}$. The absorbance decrease in $1 \mathrm{~min}$ corresponds to CAT activity. CAT activity in the supernatant was calculated using the determined extinction coefficient of $0.004(0.00394) \mathrm{mM}^{-1} / \mathrm{mm}^{-1}$ as $\mathrm{U} / \mathrm{mg}$ protein/min to the extent of dilutions made (30).

\section{Statistical analysis}

Statistical analyses were performed using the Statistical Package for the Social Sciences (SPSS Inc; Chicago, IL, USA) 17.0 package program. In descriptive statistics, continuous measurement variables were given as mean \pm , standard error as (SE), and median as (minimum-maximum). Categorical 
variables are shown as observation number and percentage values. Student's-t test was used for variables showing normal distribution in comparisons between the groups, and the Mann-Whitney $U$ test was used for variables not showing normal distribution. The differences in biochemical parameters between the groups were determined by the analysis of variance. The groups were compared one to one for each parameter using the Bonferroni test. $\mathrm{P}<0.05$ was considered to be statistically significant.

\section{Results}

To our knowledge, this is the first study where correlations between antioxidant enzyme levels-an indicator of antioxidant defense mechanisms against heavy metals and the Prx6 rs41055489 gene polymorphism were researched and reported in our country.

The Prx6 gene rs 41055489 genotype frequencies of the zebrafish are presented in Table 1 without ignoring any group. For genotype frequencies of the Prx6 rs 41055489 gene polymorphism, it was found to be $97.7 \%$ for the A/A (wild type) genotype and $2.3 \%$ for the $\mathrm{A} / \mathrm{C}$ (heterozygous) genotype. In our study, no fish carrying $(\mathrm{C} / \mathrm{C})$ in the form of polymorphic genotype homozygous was encountered (Table 1).

The frequencies of the control and Prx6 zebrafish gene rs41055489 genotype that were exposed to heavy metals are given in Table 2. The Prx6 rs41055489 genotype of only one fish was identified as heterozygous in the group (group 7), where 0.5-ppm Cd was added among the experimental groups and all fish in the other groups were found to have the wild-type genotype (Table 2).

Heavy metals $(\mathrm{Cu}, \mathrm{Cd}$, and $\mathrm{Zn})$ in different sublethal doses were applied to the commercially provided zebrafish, and the levels of LPO, antioxidative enzymes (GSH and CAT), and total protein in the gill tissues are mentioned in separate tables for each heavy metal (Table 3). The GSH level of fish (group 7) determined to be in the heterozygous genotype was $0.08804 \mu \mathrm{g} / \mathrm{mL}$, lower than the group of fish to which $\mathrm{Cd}$ was applied at the same level; the MDA level was $0.36417 \mu \mathrm{g} /$ $\mathrm{mL}$, higher than the group of fish to which $\mathrm{Cd}$ was applied at the same level. As the CAT level was below measurable limits, it could not be determined (Table 3 ).

\section{Discussion}

Genetic toxicology is a branch of science investigating toxic effects occurring in DNA. Genetic information encoded in DNA is copied and originally transferred to future generations. In a normal biological process, distortion may occur in the genetic structure as a result of the interaction of physical, chemical, and biological factors with DNA. Fishes have often been used as model organisms in the last decade for the investigation of genotoxic effects associated with aquatic ecosystems (31).
Table 1. Prx6 gene rs41055489 phenotype distributions in the zebrafish

\begin{tabular}{|l|c|c|c|}
\hline & \multicolumn{3}{c}{ Prx6 gene rs41055489 genotype frequencies } \\
\hline & $\begin{array}{c}\text { Homozygote } \\
\text { wild type } \\
\text { (A/A), n (\%) }\end{array}$ & $\begin{array}{c}\text { Heterozygote } \\
\text { (A/C), n (\%) }\end{array}$ & $\begin{array}{c}\text { Homozygote } \\
\text { polymorphic } \\
\text { (C/C), n (\%) }\end{array}$ \\
\hline Zebrafish & $42(97.7)$ & $1(2.3)$ & $0(0)$ \\
\hline
\end{tabular}

Results are expressed in numbers and percentage (\%). n: Number of samples.

Table 2. Prx6 gene rs41055489 genotype distributions in zebrafish exposed to different doses of $\mathrm{Cu}, \mathrm{Zn}$, and $\mathrm{Cd}$

\begin{tabular}{l|ccc} 
& $\begin{array}{c}\text { Prx6 gene rs41055489 genotype frequencies } \\
\text { Homozygote Heterozygote Homozygote } \\
\text { wild type } \\
\text { (A/A), n (\%) }\end{array}$ \\
\begin{tabular}{l|c} 
(A/C), n (\%) \\
polymorphic \\
(C/C), n (\%)
\end{tabular} \\
\hline Group 1 (Control) & $6(100)$ & $0(0)$ & $0(0)$ \\
Group 2 (0.1-ppm Cu) & $6(100)$ & $0(0)$ & $0(0)$ \\
Group 3 (0.5-ppm Cu) & $5(100)$ & $0(0)$ & $0(0)$ \\
\hline Group 4 (0.1-ppm Zn) & $7(100)$ & $0(0)$ & $0(0)$ \\
\hline Group 5 (0.5-ppm Zn) & $6(100)$ & $0(0)$ & $0(0)$ \\
\hline Group 6 (0.1-ppm Cd) & $8(100)$ & $0(0)$ & $0(0)$ \\
Group 7 (0.5-ppm Cd) & $4(80)$ & $1(20)$ & $0(0)$ \\
\hline Results are expressed in numbers and percentage (\%). n: Number of samples; \\
Cu: Copper; Zn: Zinc; Cd: Cadmium
\end{tabular}

GSH is important in antioxidant defense as oxygen radical scavengers. Changes in GSH levels are an important indicator of the detoxification abilities of living organisms. The GSH system in fish works by acting as a cofactor in different ways against oxidative damage. The antioxidative function of GSH occurs in cells depending on the concentration and reaction and synthesis rates. Because metal-GSH conjugation ensures the discharge of metals by way of bile, the antioxidant defense capacity decreases depending on the depletion of GSH (32). GSH levels are essential for the preservation of cellular function and may decrease in the event of detoxification and oxidative stress. However, in the event of ongoing stress, the GSH/GSSG (reduced/oxidized form of GSH) ratio increases to counteract oxidative stress with the effects of adaptive mechanisms (33). GSH, which is the substrate of many enzymatic and non-enzymatic detoxification reactions, is considered to be an effective biomarker for fish exposed to pollutants. GSH removes metals by connecting them with highly reactive sulfhydryl groups existing in its structure (34). In our study, compared to the control group, higher $\mathrm{Cu}$ doses of 0.1 and $0.5 \mathrm{ppm}$ added to the fish show that $\mathrm{Cu}$ is kept, depending on the presence of GSH in the gills. In our study, because the fish with the wild-type genotype for the Prx6 gene rs 41055489 variation was encountered in none of the groups where $\mathrm{Cu}$ was added, no comment could be made on the effects of gene polymorphism on GSH levels. 
Table 3. Antioxidative and lipid peroxidation parameters in zebrafish exposed to different doses of heavy metals

\begin{tabular}{|c|c|c|c|}
\hline & $\begin{array}{c}\text { Glutathione } \\
\text { (GSH) ( } \mu \mathrm{g} / \mathrm{mL}) \\
\text { Mean } \pm S D ; \text { Median } \\
\text { (minimum-maximum) }\end{array}$ & $\begin{array}{c}\text { Malondialdehyde } \\
\text { (MDA) ( } \mu \mathrm{g} / \mathrm{mL} \text { ) } \\
\text { Mean } \pm S D ; \text { Median } \\
\text { (minimum-maximum) }\end{array}$ & $\begin{array}{c}\text { Catalase } \\
\text { (CAT) }(\mu \mathrm{g} / \mathrm{mL}) \\
\text { Mean } \pm S D ; \text { Median } \\
\text { (minimum-maximum) }\end{array}$ \\
\hline Group 1 (Control) & $\begin{array}{c}0.0120 \pm 0.0026 ; 0.0109 \\
(0.0043-0.0207)\end{array}$ & $\begin{array}{c}0.2674 \pm 0.1361 ; 0.2052 \\
(0.0688-0.5280)\end{array}$ & $\begin{array}{c}6.8969 \pm 0.7585 ; 7.2008 \\
(3.4611-9.0553)\end{array}$ \\
\hline Group 2 (0.1-ppm Cu) & $\begin{array}{c}0.1193 \pm 0.0837 ; 0.0391 \\
(0.0152-0.5370)\end{array}$ & $\begin{array}{c}0.1084 \pm 0.0703 ; 0.0353 \\
(0.0167-0.4570)\end{array}$ & $\begin{array}{c}6.2616 \pm 0.7627 ; 5.5614 \\
(4.3627-9.3012)\end{array}$ \\
\hline Group 3 (0.5-ppm Cu) & $\begin{array}{c}0.1532 \pm 0.1229 ; 0.0261 \\
(0.0054-0.6413)\end{array}$ & $\begin{array}{c}0.1606 \pm 0.0394 ; 0.1533 \\
(0.0456-0.2664)\end{array}$ & $\begin{array}{c}7.2469 \pm 7.9295 ; 4.0758 \\
(2.0266-18.8094)\end{array}$ \\
\hline Group 4 (0.1-ppm Zn) & Insufficient number of samples & $\begin{array}{c}0.0689 \pm 0.0383 ; 0.0893 \\
(0.0246-0.928)\end{array}$ & $\begin{array}{c}9.6189 \pm 0.8769 ; 8.9839 \\
(7.3545-12.7848)\end{array}$ \\
\hline Group 5 (0.5-ppm Zn) & $\begin{array}{c}0.0380 \pm 0.0224 ; 0.0222 \\
(0.0119-0.0739)\end{array}$ & $\begin{array}{c}0.1908 \pm 0.1590 ; 0.1890 \\
(0.0066-0.3787)\end{array}$ & $\begin{array}{c}7.7684 \pm 2.3059 ; 5.5102 \\
(2.7438-15.5512)\end{array}$ \\
\hline Group 6 (0.1-ppm Cd) & $\begin{array}{c}0.0154 \pm 0.0073 ; 0.0043 \\
(0.0011-0.0478)\end{array}$ & $\begin{array}{c}0.0432 \pm 0.0105 ; 0.0473 \\
(0.0062-0.0806)\end{array}$ & $\begin{array}{c}7.3622 \pm 0.9286 ; 7.8566 \\
(4.0758-10.7151)\end{array}$ \\
\hline Group 7 (0.5-ppm Cd) & $\begin{array}{c}0.1950 \pm 0.1597 ; 0.0239 \\
(0.0142-0.8315)\end{array}$ & $\begin{array}{c}0.0930 \pm 0.0679 ; 0.0285 \\
(0.0163-0.3641)\end{array}$ & $\begin{array}{c}3.7210 \pm 1.4188 ; 3.5840 \\
(2.3750-5.2028)\end{array}$ \\
\hline
\end{tabular}

The Prx6 rs41055489 gene polymorphism was found in one zebrafish in the heterozygous form only in the group where 0.5-ppm Cd was added among all study groups. The GSH levels measured in this fish carrying the heterozygous gene polymorphism $(0.08804 \mu \mathrm{g} / \mathrm{mL})$ was found to be lower in comparison to the other fish $(0.2217 \mu \mathrm{g} / \mathrm{mL})$ to which 0.5 ppm Cd was added and had a homozygous wild-type gene polymorphism. We think that this reduction determined in the GSH level results from the inhibitory influence of an allele inactively existing in the Prx6 gene.

MDA is one of the products that form as a result of LPO and is a parameter commonly used to demonstrate oxidative damage. A high amount of MDA indicates LPO. The nonoccurrence of LPO or occurrence in low levels indicates the protective effects of oxidative enzymes. Because MDA can interact with DNA and proteins, it leads to the irreversible distortion of mechanisms that determine the functional capacity of cells (35). It has been reported that MDA exerts biological effects by forming crosslinks between DNA strands (36). It is also known that MDA forms crosslinks between DNA and protein (37). Although the results that the aforementioned genotoxic activities of MDA bring about in cells are not exactly known, they are believed to cause mutations. The damaging effect of $\mathrm{Cu}$ to DNA occurs due to its interaction with MDA. Being reduced in the first $20 \mathrm{~min}$ or oxidized, $95 \%$ of $\mathrm{Cu}$ entering the cell is activated to make the known effects. In our study, together with increasing doses of metals $(\mathrm{Cu}, \mathrm{Zn}$, and $\mathrm{Cd}$ ) added to fish in homozygous wild type for the Prx6 rs41055489 gene polymorphism, the detected decline in the
MDA levels can be interpreted to reduce the LPO activities for eliminating the damage caused by the metals in gill tissues. However, for the Prx6 rs41055489 gene polymorphism, a significant increase in MDA level detected in heterozygous fish $(0.36417 \mu \mathrm{g} / \mathrm{mL})$ reveals the nonoccurrence of the expected reduction due to the polymorphic allele.

The liver and kidney tissues of fish are rich in antioxidant defense systems such as CAT and SOD to be protected from oxidative stress caused by metals (38). CAT is a peroxidase using $\mathrm{H}_{2} \mathrm{O}_{2}$ as a substrate and breaking down oxygen $\left(\mathrm{O}_{2}\right)$ and $\mathrm{H}_{2} \mathrm{O}$, thus providing $\mathrm{H}_{2} \mathrm{O}_{2}$ detoxification. CAT, passing through all biological membranes, inactivates some enzymes. It was reported that in fish exposed to inorganic or organic contaminants, CAT activity responses depending on dose show differences in terms of induction or inhibition (39). Therefore, CAT activity determined immediately before harmful effects occurred in fish was accepted as a sensitive biomarker for oxidative stress (40). It was shown through cell culture experiments that the destruction of DNA damaged by heavy metals was tried to be completely eliminated with increased CAT activity. While cells in which DNA breaks cannot be repaired are directed to programmed cell death, transcriptional activity is completely stopped (41).

In a study where the effects of metals $(\mathrm{Cu}, \mathrm{Cd}$, iron, and nickel) to the biochemical and morphological characteristics of the gills of Channa punctata are examined, reductions depending on time have been observed in the activities of antioxidant enzymes such as CAT, GST, and SOD (42). No study showing the interaction of heavy metal and genotoxicity in 
zebrafish was found in literature. Because the expected CAT activity decreased in the Prx6 gene rs 41055489 heterozygous genotype fish in which $0.5 \mathrm{ppm} \mathrm{Cd}$ was added, the activity, which was spectrophotometrically below the measurable limit, could not be determined in this study.

\section{Conclusion}

It was determined that even the lowest sublethal doses of heavy metals activate antioxidant defense mechanisms in cells. The heterozygous form of the Prx6 rs 41055489 gene polymorphism was observed to inhibit the work of existing defense mechanisms.

Ethics Committee Approval: Ethics committee approval was received for this study from the ethics committee of Marmara University Animal Experiments.

Peer-review: Externally peer-reviewed.

Author Contributions: Concept - B.S.D., F.E.K., M.K.G., Z.A.Ü., G.K., P.Ç., Ü.Z.; Design - B.S.D., F.E.K., M.K.G., Z.A.Ü., G.K., P.Ç., Ü.Z.; Supervision - B.S.D., F.E.K., M.K.G., Z.A.Ü., G.K., P.Ç., Ü.Z.; Funding Z.A.Ü., B.S.D., F.E.K.; Materials - F.E.K., B.S.D., Z.A.Ü.; Data Collection and/or Processing - Z.A.Ü., M.K.G.; Analysis and/or Interpretation - F.E.K., P.Ç., B.S.D.; Literature Review - A.Ü., M.K.G.; Writer - B.S.D., F.E.K., M.K.G., Z.A.Ü.; Critical Review - B.S.D., F.E.K.; Other - P.Ç., Ü.Z.

Conflict of Interest: No conflict of interest was declared by the authors.

Financial Disclosure: The authors declared that this study has received no financial support.

\section{References}

1. Kenyon C. The plasticity of aging: Insights from long-lived mutants. Cel 2005; 120: 449-60. [CrossRef]

2. Wang Y, Feinstein SI, Manevich Y, Ho Y, Fisher AB. Peroxiredoxin 6 gene-targeted mice show increased lung injury with paraquat-induced oxidative stress. Antioxid Redox Signal 2006; 8: 229-37. [CrossRef]

3. Chae HZ. Cloning and sequencing of thiol-specific antioxidant from mammalian brain: Alkyl hydroperoxide reductase and thiol-specific antioxidant define a large family of antioxidant enzymes. Proc Natl Acad Sci USA 1994; 91: 7017-21. [CrossRef]

4. Wood ZA, Schroder E, Robin Harris J, Poole LB. Structure, mechanism and regulation of peroxiredoxins. Trends Biochem Sci 2003; 28: 32-40. [CrossRef]

5. Choi HJ, Kang SW, Yang CH, Rhee SG, Ryu SE. Crystal structure of a novelhuman peroxidase enzyme at $2.0 \AA$ A resolution. Nat Struct Biol 1998; 5: 400-6. [CrossRef]

6. Wong CM, Siu KL, Jin DY. Peroxiredoxin-null yeast cells are hypersensitive to oxidative stress and are genomically unstable. J Biol Chem 2004; 279: 23207-13. [CrossRef]

7. Radyuk SN, Klichko VI, Spinola B, Sohal RS, Orr WC. The peroxiredoxin gene family in Drosophila melanogaster. Free Radic Biol Med 2001; 31: 1090-100. [CrossRef]

8. Wood ZA, Schro"der E, Haris JR, Poole LB. Structure, mechanism and regulation of peroxiredoxins. Trends Biochem Sci 2003; 28: 32-40. [CrossRef]

9. Chae HZ, Robison K, Pooleo LB, Church G, Storz G, Rhee SG. Cloning and sequencing of thiol-specific antioxidant from mammalian brain: alkyl hydroperoxide reductase and thiol-specific antioxidant define a large family ofantioxidant enzymes. Proc Natl Acad Sci U S A 1994; 91: 7017-21. [CrossRef]
10. David E, Tanguy A, Moraga D. Peroxiredoxin 6 gene: a new physiological and genetic indicator of multiple environmental stress response in Pacific oyster Crassostrea gigas. Aquat Toxicol 2007; 84: 389-98. [CrossRef]

11. Wang Q, Chen KP, Yao Q, Zhao Y, Li YJ, Shen H, et al. Identification and characterization of a novel 1-Cys peroxiredoxin from silkworm. Bombyx mori. Comp Biochem Physiol B 2008; 149: 176-82. [CrossRef]

12. Kang SW, Baines IC, Rhee SG. Characterization of a mammalian peroxiredoxin that contains one conserved cysteine. J Biol Chem 1998; 273: 6303-11. [CrossRef]

13. Park H, Ahn IY, Kim H, Cheon J, Kim M. Analysis of ESTs and expression of two peroxiredoxins in the thermally stressed Antarctic bivalve Laternula elliptica. Fish Shellfish Immunol 2008; 25: 550-9. [CrossRef]

14. Zhang, Q, LiF Zhang J, Wang B, Gao H, Huang B. Molecular cloning, expression of a peroxiredoxin gene in Chinese shrimp Fenneropenaeus chinensis and the antioxidant activityofitsrecombinantprotein. Mol Immunol 2007; 44: 3501e9.

15. Nikapitiya C, De Zoysa M, Whang I, Ki CG, Lee YH, Kim SJ, et al. Molecular cloning, characterization and expression analysis of peroxiredoxin 6 from disk abalone Haliotis discus discus and the antioxidant activity of it srecombinant protein. Fish Shellfish Immunol 2009; 27: 239-49. [CrossRef]

16. David E, Tanguy A, Moraga D. Peroxiredoxin 6 gene: a new physiological and genetic indicator of multiple environmental stres responsein Pacific oyster Crassostrea gigas. Aquat Toxicol 2007; 84: 389-98. [CrossRef]

17. Loumaye E, Andersen AC, Clippe A, Degand H, Dubuisson M, Zal F, et al. Cloning andcharacterizationof Arenicola marina peroxiredoxin 6,anannelid twocysteine peroxiredoxin highly homologous to mammalian one-cysteine peroxiredoxins. Free Radic Biol Med 2008; 45: 482-93. [CrossRef]

18. Available from: http://www.ncbi.nlm.nih.gov/gene

19. Available from: http://www.ncbi.nlm.nih.gov/projects/SNP/snp_ref. cgi? rs $=41055489$

20. Garcia-Santos S, Fontainhas-Fernandes A, Wilson JM. Cadmium tolerance in the Nile tilapia (Oreochromis niloticus) following acute exposure assessment of some ionoregulatory parameters. Environ Toxicol 2006; 21: 33-46. [CrossRef]

21. Bay S, Greenstein D, Szalay P, Brown D. Exposure of scorpionfish (Scorpaena guttata) to cadmium: biochemical effects of chronic exposure. Aquatic Toxicol 1990; 16: 311. [CrossRef]

22. Cousıns RJ, Leinart AS. Tissuespecific regulation of zinc metabolism and metallothionein genes by interleukin. 1. FASEB J 1998; 2: 2884-90.

23. Kamunde C, Clayton C, Wood CM. Waterborne vs. dietary copper uptake in rainbow trout and the effects of previous waterborne copper exposure. Am J Physiol Regul Integr Comp Physiol 2002; 283: R69-78. [CrossRef]

24. Gagnon A, Jumarie C, Hontela A. Effects of $\mathrm{Cu}$ on plasma cortisol and cortisol secretion by adrenocortical cells of rainbow trout (Oncorhynchus mykiss). Aquatic Toxicol 2006; 78: 59-65. [CrossRef]

25. Watson TA, Beamısh FW. The effects of zinc on branchial adenosine triphosphatase enzymes in vitro from rainbow trout, Salmo Gairdneri. Comp Biochem Physiol C 1981; 68: 167-73. [CrossRef]

26. OECD. 1999. Available from: http://www.oecd.org/dac/environmentdevelopment/1884214.pdf.

27. Available from: www.roche-applied-science.com

28. Ledwozyw A, Michalak D, Stepien A, Kadziolka A. The relationship between plasma triglycerides, cholesterol, total lipids and lipid peroxidation products during human atherosclerosis. Clin Chim Acta 1986; 155: 27583. [CrossRef]

29. Beutler E. Glutathione in Red Cell Metabolism: A Manual of Biochemical Methods. 2nd ed., Grune and Stratton, N.Y. 1975; 112-4.

30. Aebi H. Catalase in vitro. Meth Enzymol 1984; 105: 121-6. [CrossRef]

31. Akbulut C, Kızıl Ç, Yön ND. Effects of low doses of bisphenol a on primordial germ cells in zebrafish (Danio rerio) embryos and larvae. Kafkas Univ Vet Fak Derg 2013; 19: 647-53. [CrossRef] 
32. Fırat Ö, Çogun HY, Aslanyavrusu S, Kargın F. Antioxidant responses and metal accumulation in tissues of Nile tilapia Oreochromis niloticus under Zn, Cd and Zn + Cd exposures. J Appl Toxicol 2009; 29: 295301. [CrossRef]

33. Zhang JF, Liu H, Sun YY, Wang XR, Wu JC, Xue YQ. Responses of the antioxidant defenses of the Goldfish Carassius auratus, exposed to 2,4-dichlorophenol. Environ Toxicol Pharmacol 2005; 19: 185-90. [CrossRef]

34. Viarengo A, Canesi L, Martinez PG, Peters LD, Livingstone DR. Prooxidant processes and antioxidant defence systems in the tissues of the antarctic scallop (Adamussium codbecki) compared with the Mediterranean scallgo (Pecten jacobaeus). Comp Biochem Physiol 1995; 111: 119-26. [CrossRef]

35. Uchida K. Role of reactive aldehyde in cardiovascular diseases. Free Radic Biol Med 2000; 28: 1685e96.

36. Niedernhofer LJ, Daniels JS, Rouzer CA, Greene RE, Marnett LJ. Malondialdehyde, a product of lipid peroxidation,is mutagenic in human cells. J Biol Chem 2003; 278: 31426e33.

37. Voitkun V, Zhitkovich A. Analysis of DNA-protein crosslinking activity of malondialdehyde in vitro. Mutat Res 1999; 424: 97e106.
38. Basha PS, Rani AU. Cadmium-induced antioxidant defense mechanism in freshwater teleost Oreochromis mossambicus (Tilapia). Ecotoxicol Environ Saf 2003; 56: 218-21. [CrossRef]

39. Romeo M, Bennani N, Gnassia-Barelli M, Lafaurie M, Girard JP. Cadmium and copper display different responses towards oxidative stress in the kidney of the sea bass Dicentrarchus labrax. Aquat Toxicol 2000; 48: 185-94. [CrossRef]

40. Gül Ş, Belge-Kurutaş E, Yıldız E, Şahan A, Doran F. Pollution correlated modifications of liver antioxidant systems and histopathology of fish (Cyprinidae) living in Seyhan Dam Lake, Turkey. Environ Int 2004; 30: 605-9. [CrossRef]

41. Vöhringer ML, Becker TW, Krieger G, Jacobi H, Witte I. Synergistic DNA damaging effects of malondialdehyde/Cu(II) in PM2 DNA and in human fibroblasts. Toxicol Lett 1998; 94: 159-66. [CrossRef]

42. Pandey S, Parvez S, Ansari RA, Ali M, Kaur M, Hayat F, et al. Effects of exposure to multiple trace metals on biochemical, histological and ultrastructural features of gills of a freshwater fish, Channa punctata Bloch. Chem Biol Interact 2008; 174: 183-92. [CrossRef] 